Article

\title{
Experimental Hypomagnesemia Induces Neurogenic Inflammation and Cardiac Dysfunction
}

\author{
Jay H. Kramer ${ }^{1, *}$, I. Tong Mak ${ }^{1, *}$, Joanna J. Chmielinska ${ }^{1}$, Christopher F. Spurney ${ }^{2}$, \\ Terry M. Phillips ${ }^{3}$ and William B. Weglicki ${ }^{1}$ \\ 1 Department of Biochemistry \& Molecular Medicine, The George Washington University, \\ Washington, DC 20037, USA; phyjch@gwu.edu (J.J.C.); wweg@gwu.edu (W.B.W.) \\ 2 Division of Cardiology, Children's National Medical Center, Washington, DC 20010, USA; \\ cspurney@cnmc.org \\ 3 Affiliate Professor of Pharmaceutics, Virginia Commonwealth University, Richmond, VA 23284, USA; \\ tmphil46@yahoo.com \\ * Correspondence: phyjhk@gwu.edu (J.H.K.); itmak@gwu.edu (I.T.M.); Tel.: +1-202-994-0502 (J.H.K.); \\ Tel.: +1-202-994-2865 (I.T.M.)
}

Received: 23 July 2020; Accepted: 2 September 2020; Published: 5 September 2020

\begin{abstract}
Hypomagnesemia occurs clinically as a result of restricted dietary intake, Mg-wasting drug therapies, chronic disease status and may be a risk factor in patients with cardiovascular disorders. Dietary restriction of magnesium ( $\mathrm{Mg}$ deficiency) in animal models produced a pro-inflammatory/pro-oxidant condition, involving hematopoietic, neuronal, cardiovascular, renal and other systems. In Mg-deficient rodents, early elevations in circulating levels of the neuropeptide, substance P (SP) may trigger subsequent deleterious inflammatory/oxidative/nitrosative stress events. Evidence also suggests that activity of neutral endopeptidase (NEP, neprilysin), the major SP-degrading enzyme, may be impaired during later stages of $\mathrm{Mg}$ deficiency, and this may sustain the neurogenic inflammatory response. In this article, experimental findings using substance P receptor blockade, NEP inhibition, and N-methyl-D-aspartate (NMDA) receptor blockade demonstrated the connection between hypomagnesemia, neurogenic inflammation, oxidative stress and enhanced cardiac dysfunction. Proof of concept concerning neurogenic inflammation is provided using an isolated perfused rat heart model exposed to acute reductions in perfusate magnesium concentrations.
\end{abstract}

Keywords: magnesium deficiency; substance $P$ and substance $P$ receptor blockade; neutral endopeptidase inhibition; NMDA receptor blockade; inflammatory cytokines; oxidative/nitrosative stress; neutrophil superoxide generation; RBC glutathione; cardiac dysfunction; perfused rat heart model

\section{Introduction}

Hypomagnesemia is frequently associated with clinical disorders such as diabetes, metabolic syndrome, alcoholism, HIV-1 infection, cancer, and cardiovascular diseases, or as a consequence of low dietary magnesium $(\mathrm{Mg}$ ) intake, GI/renal malabsorption, or Mg-wasting drug therapies [1-3]. Since hypomagnesemia can occur in patients with restricted dietary magnesium intake and magnesium-wasting drugs, clinically significant hypomagnesemia can be a problem, especially in patients with heart disease. In one report [4], 10 20\% of hospitalized patients had hypomagnesemia, and this was most common in critically ill patients, and in those with heart failure. Hypomagnesemia has been linked to cardiac arrhythmias and vasospasm and may be a risk factor for patients with cardiovascular disease $[3,5,6]$. Using animal models of hypomagnesemia, progressive development of cardiovascular lesion formation $[7,8]$ as well as enhanced myocardial vulnerability to toxic agents [3] and secondary stresses [7,9] including ischemia/reperfusion [10-13], have been reported. When 
antioxidants were administered in vivo to rodents with hypomagnesemia, the severity of cardiac inflammation [8] and reperfusion injury [12] were reduced, suggesting a pro-oxidant mechanism. Indeed, a clinical study supports the notion that magnesium deficiency potentiated free radical production associated with myocardial infarction [14]. Animal models of hypomagnesemia are also characterized by increased levels of inflammatory mediators and decreased endogenous antioxidants $[13,15,16]$. The discovery that these changes were preceded by heightened circulating levels of substance P (SP) $[15,17,18]$ led to the hypothesis [19] that this neuropeptide initiates a cascade of oxidative/nitrosative events in this model. In this article, we provide key experimental findings linking chronic hypomagnesemia to SP-mediated inflammation, oxidative/nitrosative stress, enhanced cardiac dysfunction, and reduced tolerance to postischemic stress. Moreover, we also demonstrated the sensitive relation between acute reductions in extracellular magnesium content and the triggering of neurogenic inflammation, inflammatory cytokine release and associated loss of mechanical function in an ex vivo perfused working rat heart model.

\section{Results and Discussion}

\subsection{Substance P Elevations and Oxidative Stress During Experimental Mg Deficiency}

Using both rat and mouse models $[17,18,20]$, heightened levels of circulating substance P (SP) during severe diet-induced $\mathrm{Mg}$ deficiency (9\% of recommended daily allowance [RDA] for $\mathrm{Mg}$ ) occurred, with the earliest significant increase detected by dietary day 3 , and peaking by day 7 . This preceded the elevations in circulating inflammatory cytokines (IL-1, IL-6, and TNF $\alpha$ ) which began after dietary day 12. A second rise in circulating SP began after two weeks (days 17-21) of Mg deficiency, coinciding with inactivation of neutral endopeptidase (NEP), the primary SP-degrading protease [21,22]. Proportionally smaller elevations in SP occurred in rats fed moderate Mg-deficient diets (20 and 40\% of RDA) for 3 weeks [23]; circulating total SP levels for moderately deficient (40\% RDA) rats were approximately half of the severely deficient animals, suggesting that the magnitude of the SP elevation was influenced by dietary Mg-intake. Proportional changes in associated oxidative stress markers, red blood cell (RBC) glutathione (GSH) and plasma malondialdehyde, were also displayed in 3 week moderate and severe Mg-deficient rats [23]: plasma malondialdehyde formation was elevated by 60 and 148\% in moderate and severe Mg-deficient rats, and RBC glutathione levels fell by $29 \%$ in moderate and by $50 \%$ in severe $\mathrm{Mg}$-deficient rats.

After the initial transient rise in circulating SP during week 1 of severe $\mathrm{Mg}$ deficiency, greater subsequent elevations were observed at week 3 (7.2-fold higher than control) and this continued to week 5 (6.5-fold) (Figure 1) [24]. Plasma isoprostane levels were elevated $80 \%$ at week 3 and $210 \%$ at week 5 (Figure 2), suggesting progressive lipid peroxidation during the later phase of Mg deficiency. RBC glutathione levels remained approximately 50\% lower than control in 5 week severe Mg-deficient rats (Figure 2). Indeed, circulating PMNs from 5 week Mg-deficient rats exhibited a 4- to 5-fold higher basal superoxide $\left(\mathrm{O}_{2}^{-}\right)$-generating activity (Figure 2); with phorbol myristate acetate (PMA) stimulation, these PMNs displayed greater than 2-fold higher activity. These findings indicated that the superoxide production by PMNs of Mg-deficient rats was substantially augmented with prolonged Mg deficiency.

\subsection{Substance P (Neurokinin-1 or NK-1) Receptor during Mg Deficiency}

The status of the SP (neurokinin-1 or NK-1) receptor is also altered during Mg deficiency, and antagonists which target the SP receptor render protection by inhibiting SP bioactivity. The tachykinin NK-1 receptor is a member of the rhodopsin-like family of G protein-coupled receptors [25-27], and is found in neurons, vascular endothelial cells, muscle, gastrointestinal tracts, pulmonary tissue, thyroid gland and in different types of immune cells [25,27-29]. SP acts through its receptor on inflammatory cells [30] and can elicit multiple responses including: the promotion of 
leukocyte adhesion [31], the activation of macrophages [32]; induction of endothelial cells to generate NO• [33]; and priming of PMNs for superoxide production [34].

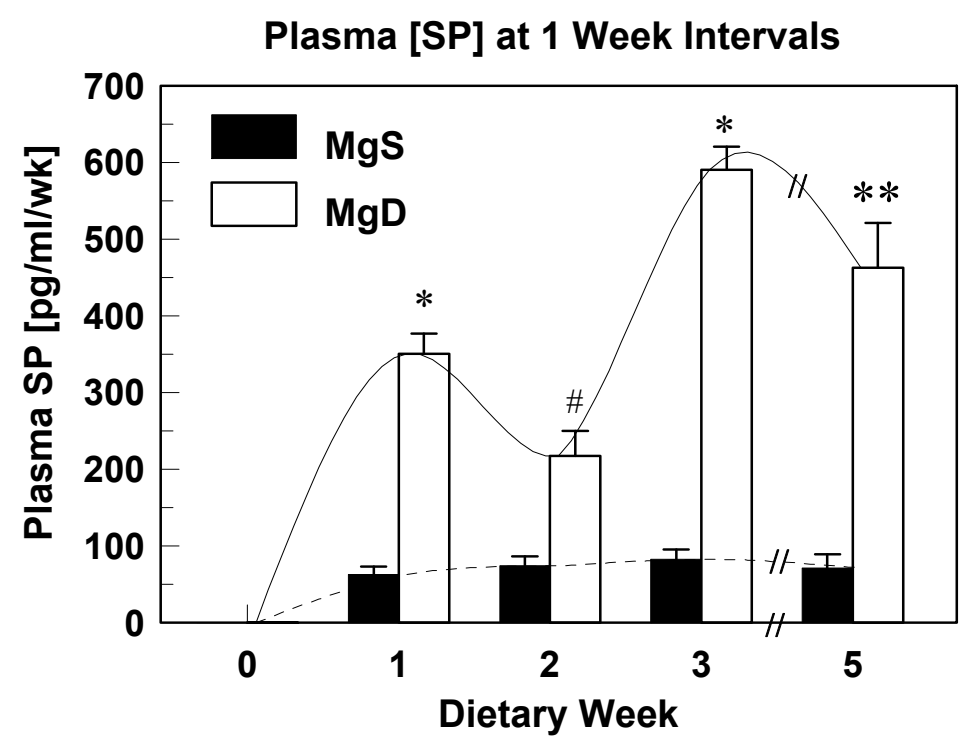

Figure 1. Effect of extending severe dietary $\mathrm{Mg}$ deficiency $(\mathrm{MgD})$ exposure to 5 weeks on rat plasma substance $p$ levels ( 1 week intervals). SP levels were determined with a commercial colorimetric 96 well ELISA kit from R\&D Systems (Minneapolis, MN). After normalizing to baseline, time-course data were integrated over the specified 7 day periods, and values are means $\pm \mathrm{SE}$ from five rats. ${ }^{\#} p<0.02,{ }^{* *}$ $p<0.01,{ }^{*} p<0.001$ vs. Mg sufficient $(\mathrm{MgS})$.

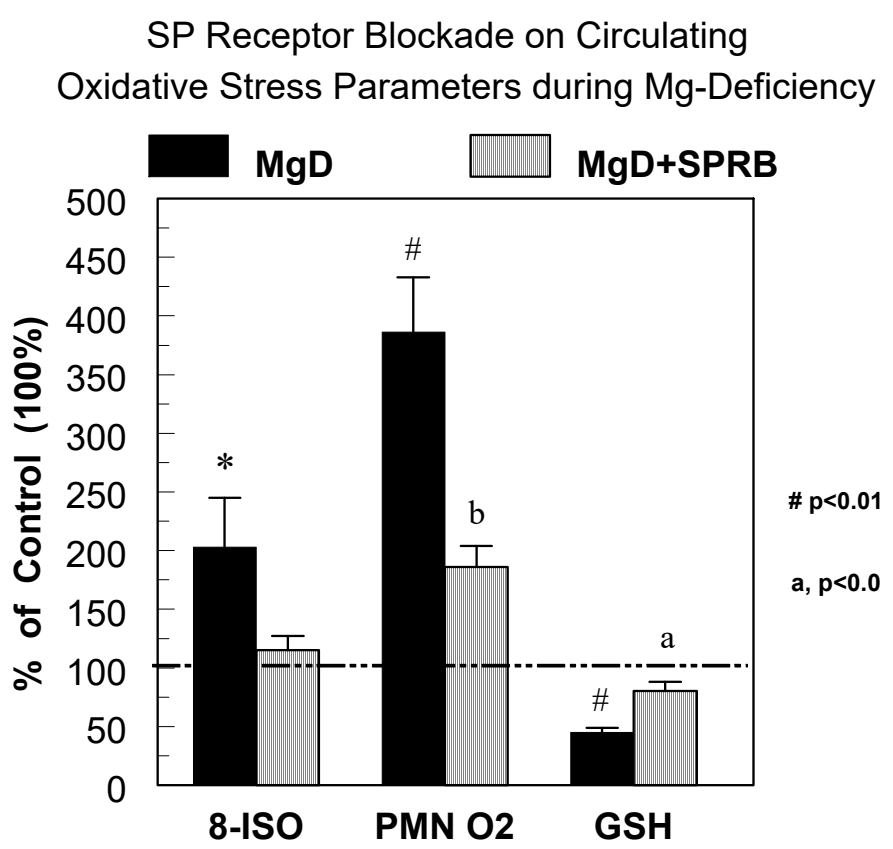

Figure 2. Effects of extending dietary $\mathrm{Mg}$ deficiency $(\mathrm{MgD})$ exposure to 5 weeks with or without substance P receptor blockade (SPRB: L-703,606, $1.0 \mathrm{mg} / \mathrm{kg} /$ day s.c. pellet) on rat plasma 8-isoprostane levels (immunoassay kit from Cayman Chemical); neutrophil (PMN) basal superoxide-generating activity (SOD-inhibitable cytochrome c reduction assay), and RBC glutathione (GSH) loss. Values are means \pm SE from five rats. ${ }^{*} p<0.05,{ }^{\#} p<0.01$ vs. Mg-sufficient $(\mathrm{MgS})$ control; ${ }^{\mathbf{a}} p<0.01 .{ }^{\mathbf{b}} p<0.05$ vs. $\mathrm{MgD}$ alone. Modification of figure in citation \# [24]. 
Treatment of severe Mg-deficient rats for 3 or 5 weeks with the SP receptor blocker (SPRB), L-703,606, significantly attenuated circulating neutrophil production of ROS (Figure 2), indicating SP-mediated activation [35]; moreover, L-703,606 treatment lowered isoprostane levels (Figure 2), preserved RBC glutathione (Figure 2), and the 13-fold increase in plasma $\mathrm{PGI}_{2}$ was dramatically reduced by $80 \%$. Treatment with another SP receptor antagonist, CP-96,345, prevented most of the decrease in RBC glutathione as well as the rise in plasma lipid peroxidation products (thiobarbituric acid-reactive substance) [18]. Interestingly, SP receptor inhibition significantly blocked the loss of circulating neutrophil NEP activity after 3 and 5 weeks of Mg deficiency [22]. Collectively, these findings strongly indicated that SP initiates PMN activation, and systemic free radical stress leading to endogenous antioxidant depletion during chronic dietary $\mathrm{Mg}$ deficiency.

Since our initial report of SP-mediated inflammation/oxidative stress during MgD in rodents [19], other investigators have made similar observations of $\mathrm{MgD}$ associated neurogenic inflammation in clinical disorders including osteoporosis [36], traumatic brain injury [37], and Tourette's syndrome [38]. Moreover, a recent review [39] has focused attention on SP and its profound role in adverse cardiac remodeling and cardiac inflammation involving release of pro-inflammatory cytokines and matrix metalloproteases from immune and cardiac mast cells.

\subsection{Substance P Receptor Blockade Attenuates Mg Deficiency-Induced Cardiac Dysfunction}

The impact of chronic dietary Mg deficiency with or without SP receptor blockade on cardiac function in rats was investigated using non-invasive transthoracic echocardiography [24]. Rats placed on a Mg-deficient diet were treated with L-703,606 or placebo, and then echocardiography was periodically conducted [22]. Three weeks of Mg deficiency only caused a $20 \%$ decline in the mitral valve $\mathrm{E} / \mathrm{A}$ ratio (early/late [A = atrial] ventricular filling velocity), a sign of early diastolic dysfunction (Figure 3C). Aortic pressure maximum (Pmax) was non-significantly depressed approximately 15\% at 3 weeks (Figure 3D). LV systolic function (Figure 3A: LV ejection fraction, LVEF; and Figure 3B: \% fractional shortening, \% FS) were not significantly affected at 3 weeks. By contrast, 5 weeks of $\mathrm{Mg}$ deficiency led to significant $(p<0.05)$ depression in LV systolic function (Figure 3A: 8.9\% lower LVEF; and Figure 3B: $16.5 \%$ lower \%FS), aortic pressure max (Figure 3D: Pmax) was reduced $24.4 \%$, and LV diastolic function (Figure 3C: E/A) was depressed 28\%. Five weeks of concurrent L-703,606 treatment (Figure 3A-D) led to improvement in all described parameters (LVEF, \%FS, E/A and Pmax increased by $38,42,54$, and $59 \%$, respectively). This partial protection by the SP receptor blocker suggests a causal role for SP in the development of oxidative injury and cardiac dysfunction during prolonged $\mathrm{Mg}$ deficiency. Thus, $\mathrm{Mg}$ deficiency caused progressive cardiac systolic and diastolic dysfunction in rats and is associated with SP-mediated stress.

\subsection{Modulation of Neuronal Substance P Release}

Evidence $[19,23]$ also suggested that the early SP release during dietary week 1 relied on enhanced calcium influx into neuronal tissue, via either voltage-dependent calcium channels or the ligand-gated $\mathrm{N}$-methyl-D-aspartate (NMDA) receptor/calcium channel complex [40-42]. The increase in intracellular calcium is likely the priming event for the increased SP release that subsequently induced the increase in inflammatory cytokines. Moreover, the increase in intracellular calcium activates nuclear factor kappa beta (NFk $\beta$ ), a transcription factor responsible for expression of inflammation-related genes [43].

Due to the relatively short half-life (minutes) of released SP, the peripheral C-fiber neurons and dorsal root ganglia, rather than CNS (brain and spinal cord), are the likely sources of this neuropeptide [44-47] during $\mathrm{Mg}$ deficiency. We contend that this process is primarily modulated by the Mg-gated NMDA receptor/channel complex due to declining extracellular Mg levels [48,49]. 

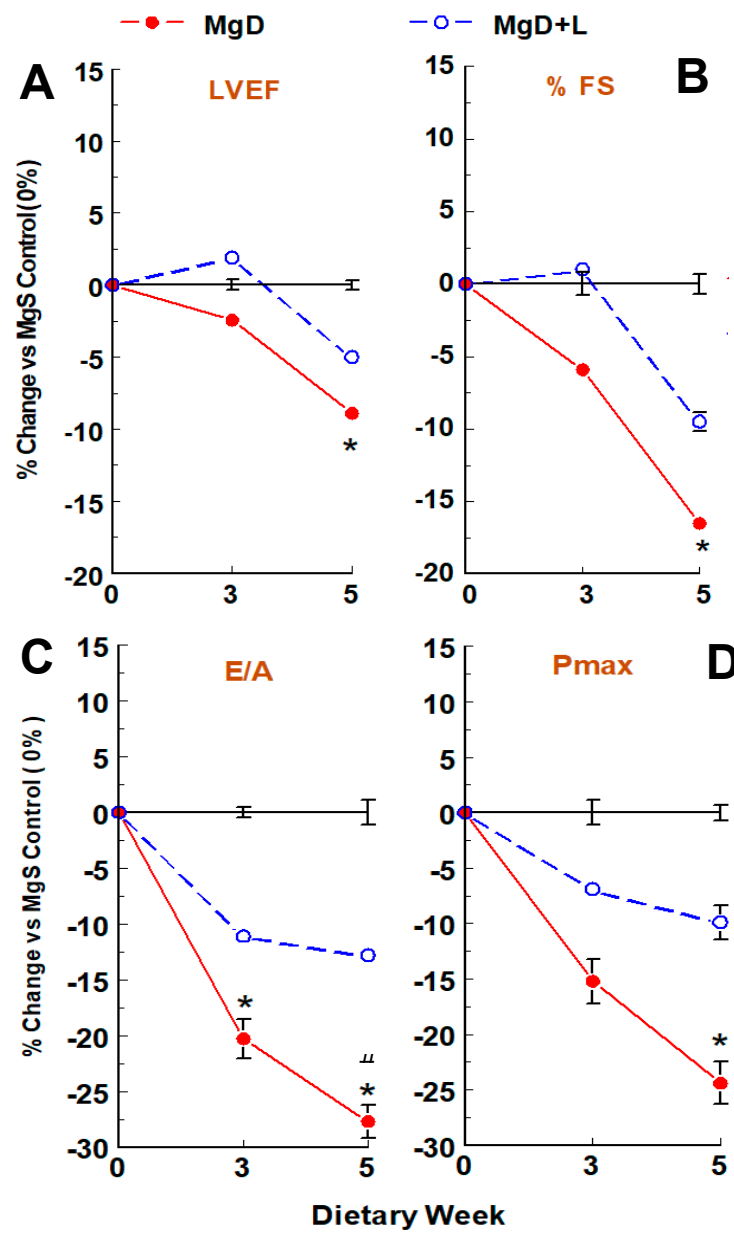

Figure 3. Effects of extending the diet period to 5 weeks on echocardiographic parameters of Mg-deficient $(\mathrm{MgD})$ rats with or without SP receptor blockade (L: L-703,606, $1.0 \mathrm{mg} / \mathrm{kg} /$ day s.c. pellet). Values are means \pm SE of five rats. Absent SEMs are within symbol size. (A): LVEF = left ventricular ejection fraction; (B): \% FS = left ventricular \% fractional shortening; (C): E/A = mitral value E/A wave ratio (early/late $\left[\mathrm{A}=\right.$ atrial] ventricular filling velocity); and (D): Pmax = Aortic pressure maximum. ${ }^{*} p<$ 0.05 vs. MgS; $\# p<0.05$ vs. $\mathrm{MgD}+\mathrm{L}$.

The early elevation in circulating SP likely involves SP-rich C fibers of the dorsal root ganglia (DRG). When DRG isolated from both Mg-deficient and Mg-sufficient rats were immunostained for SP [50], both exhibited comparable SP staining intensity at 1 week; however, SP staining intensity was substantially reduced after 2 and 3 weeks of $\mathrm{Mg}$ deficiency. In addition, treatment of Mg-deficient rats with a non-competitive NMDA receptor/channel antagonist, MK-801 (dizolcipine), prevented much of the loss in SP staining intensity.

During continuous MK-801 treatment for 3 weeks in Mg-deficient rats, depression in plasma SP levels was observed at all examined time intervals (Figure 4), and area integration of the 3 week time courses revealed an overall 50\% reduction in total SP (Figure 4A). Interestingly, MK-801's impact was greatest during week 1 (Figure 4B: 90\% lower) of Mg deficiency compared to weeks 2 (50\%) and 3 $(30 \%)$. This suggests that SP elevation/release during weeks 2 and 3 may not entirely dependent on. 

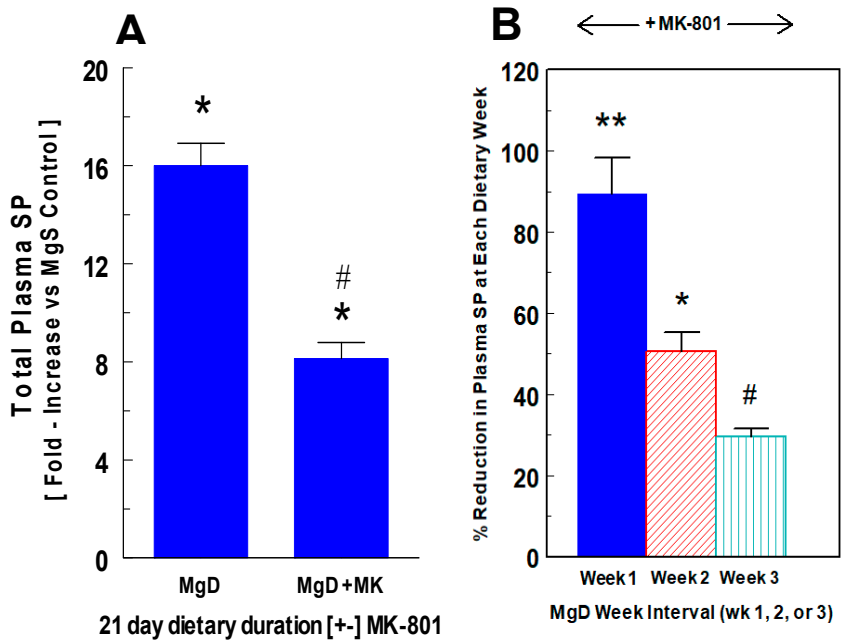

Figure 4. Effect of the NMDA receptor/channel inhibitor, MK-801 (0.5 mg/kg/day, s.c. time release pellet), on reduction in total plasma SP levels (ELISA) during the initial 3 week dietary period (A): left panel) and at 1 week intervals (B): right panel, weeks 1, 2 and 3) of severe Mg deficiency (MgD). After normalizing to baseline, time-course data were area integrated over the specified time intervals, and values are means \pm SE from five rats/group. Left panel: ${ }^{*} p<0.05 \mathrm{vs.} \mathrm{MgS} \mathrm{control,} \# p<0.01 \mathrm{vs}$. MgD alone; Right panel: $\# p<0.05,{ }^{*} p<0.02,{ }^{* *} p<0.01$ vs. MgD alone.

Furthermore, elevated circulating prostaglandin E2 $\left(\mathrm{PGE}_{2}\right)$ levels were dose-dependently reduced towards control levels by MK-801 [50]. This elevation in prostanoid product levels indicated endothelial activation during $\mathrm{Mg}$ deficiency, and heightened responsiveness to SP. MK-801 treatment preserved the loss of RBC glutathione during week 1 of $\mathrm{Mg}$ deficiency but was more effective during weeks 2 and 3 (Figure 5 : 38 and 56\% improved). Collectively, these findings suggest that enhanced neuronal SP release during early $\mathrm{Mg}$ deficiency triggered the increased severity of in vivo oxidative/nitrosative stress during subsequent weeks of this dietary model.

\section{Effect of NMDA Receptor Blockade on RBC GSH Loss in $\mathrm{MgD}_{9}$ Rats}

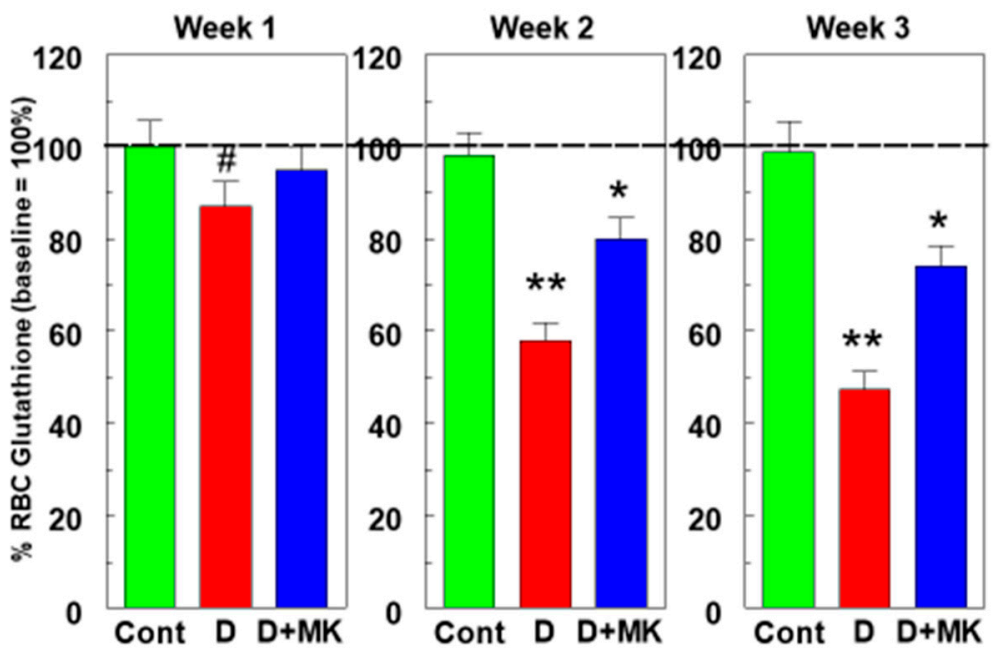

Figure 5. Effect of the NMDA receptor/channel inhibitor, MK-801 $(0.5 \mathrm{mg} / \mathrm{kg} /$ day, s.c. time release pellet), on RBC glutathione loss (spectrocolorimetric assay) in rats at 1,2 and 3 weeks of dietary $\mathrm{Mg}$ deficiency. Values are means $\pm \mathrm{SE}$ of five rats/group. $\# p<0.05,{ }^{* *} p<0.01$ vs. control; ${ }^{*} p<0.05$ vs. D (MgD) alone. 


\subsection{Mg Deficiency-Mediated Cardiac Inflammation is Reduced by NMDA Receptor Blockade}

After one week of severe $\mathrm{Mg}$ deficiency in rats, enhanced immunostaining for cardiac tissue SP and SP (neurokinin-1, NK-1) receptor was observed, along with a substantial increase $(40 \%$ higher) in expression of vascular endothelial growth factor (VEGF), which remained elevated through week 3 [51]. In addition, elevated expression of endothelial adhesion molecule iCAM-1 (CD54), the monocyte/macrophage cell surface marker CD11b ( $\alpha$ M integrin) [50] and endotoxin receptor CD14 [52], were observed. MK-801 attenuated cardiac tissue inflammation, as evidenced by the decreased expression of VEGF [51], iCAM-1, and CD11b during Mg deficiency [50]. This suggests that the decreased release of SP lowered expression of these indices of tissue inflammation [18].

Severe $\mathrm{Mg}$ deficiency also promoted angiogenesis [53], as well as significant apoptosis in rat hearts after 3 weeks; this was suggested by elevated caspase 3 enzyme activity (3.9-fold higher than control) and its product, cleaved poly (ADP-ribose) polymerase (PARP cleavage: 4.6-fold higher than control) [54]. The causal role of SP in development of apoptosis during Mg deficiency was also addressed by assessing the effect of MK-801 on DNA fragmentation in cardiac tissue sections. Although less than $1 \%$ of nuclei were positive for apoptosis in control heart tissue, $33 \%$ of apoptotic nuclei were observed in Mg-deficient tissue. In vivo treatment with MK-801 significantly decreased the number of apoptotic nuclei by $40 \%$. Thus, $\mathrm{Mg}$ deficiency-induced apoptosis in rat hearts was ameliorated by NMDA receptor blockade.

\subsection{Non-NMDA Receptor Modulation of Substance P Levels}

As suggested by our MK-801 treatment study (Figure 4), the neuronal-NMDA receptor/channel release mechanism may only be partially responsible for the subsequent increases in circulating SP observed during dietary weeks 3 and 5 (Figure 1). An alternative explanation for the heightened circulating SP levels at these later times of hypomagnesemia may involve a contribution of new SP synthesis from non-neuronal sources. RT-PCR analyses of inflammatory (macrophages, mast cells, monocytes, neutrophil) and endothelial cells showed that these non-neuronal cells possess mRNA for SP as well as for its bioactive neurokinin-1 [NK-1] receptor, implicating the potential for de novo synthesis [55-58]. Thus, the possibility of a non-neuronal origin of circulating SP elevations during later periods of $\mathrm{Mg}$ deficiency should be further considered. In view of the important role of phagocytic cells in the inflammatory process and their contribution towards generating reactive oxygen species, these cells promote oxidative and inflammatory stress that increases the risk for cardiovascular disease.

\subsection{Neutral Endopeptidase (NEP) Modulates Substance P Levels During Mg Deficiency}

An equally plausible explanation for the heightened SP levels during later periods of $\mathrm{Mg}$ deficiency may involve the status of neutral endopeptidase or neprilysin (NEP: EC 3.4.24.11; CD10). NEP is the primary proteolytic SP-degrading enzyme [59], but others may degrade SP to a lesser extent [60]. NEP is a cell surface metalloprotease which is expressed by various cells and tissues such as the small intestine, kidney, airway epithelium, brain, heart, vascular endothelium [61], macrophages [62], and neutrophils [63]. NEP can also be a target of lipid peroxidation by-products such as 4-hydroxynonenal (4-HNE), which can form covalent adducts with lysine and histidine residues of the enzyme [64,65]. Indeed, increased levels of NEP-HNE adducts have been detected in the brain tissue of the elderly and were higher in tissue samples from Alzheimer patients [65]. In the hypomagnesemic rodent model, the enhanced oxidative/nitrosative events may inactivate NEP and partly account for the heightened circulating SP levels during weeks 3 and 5 of Mg deficiency.

\subsection{NEP Inhibition Modulates SP Bioavailability}

Using the NEP inhibitor, phosphoramidon (PR), the influence of NEP inhibition on circulating SP levels (ELISA) in rats was investigated [66]. During severe Mg deficiency, area integration of the one-week time course demonstrated a 7.5 -fold increase in total SP $(0.473 \mathrm{ng} / \mathrm{mL} / \mathrm{wk}$, normalized 
to baseline) [21] and PR treatment caused further significant increases in SP levels (2.45-fold higher than Mg deficiency alone). This has been further documented in Figure 6, which shows that PR treatment not only substantially elevated SP levels at all sampling days during dietary week 1 but does so at an earlier onset ( $\leq 3$ days) compared to Mg deficiency alone. We concluded that NEP strongly influenced SP bioavailability during early Mg deficiency. Moreover, in keeping with our observations in Figure 4, NMDA receptor blockade with MK-801 caused a considerable reduction in plasma SP throughout the 1 week dietary period (Figure 6), supporting the notion of the neuronal origin of SP during this early period.

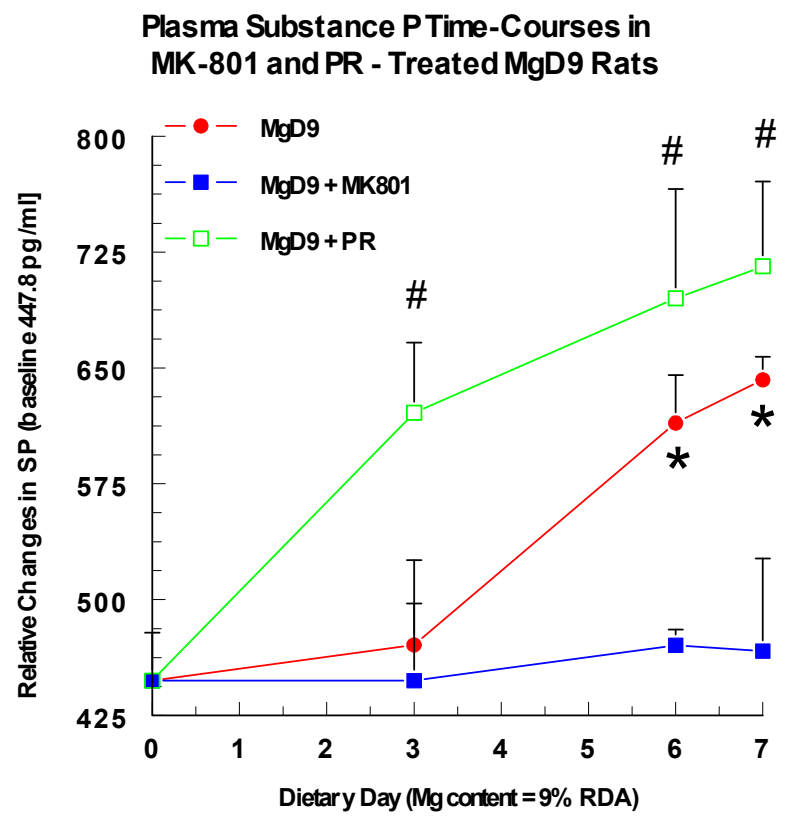

Figure 6. Plasma substance $\mathrm{P}$ time courses in Mg-deficient rats treated with a neutral endopeptidase (NEP) inhibitor or NMDA receptor blocker for 1 week. Rats were placed on Mg-deficient $\left(\mathrm{MgD}_{9}\right.$, containing $9 \%$ of control Mg) or control Mg-sufficient (MgS, containing 100\% RDA Mg) diets with or without concurrent phosphoramidon (NEP inhibitor, PR: $5 \mathrm{mg} / \mathrm{kg} /$ day, s.c. pellet) or NMDA receptor inhibition with MK-801 (0.5 mg/kg/day, s.c. pellet). Plasma SP levels were measured using a colorimetric ELISA kit from R\&D Systems and were not baseline adjusted. Plasma SP baseline levels in rats = $447.6 \pm 31 \mathrm{pg} / \mathrm{mL}$. Values are means \pm SE of $4-6$ rats. ${ }^{*}$ and $\# p<0.05$ and 0.02 vs. baseline (day 0 ). Modification of figure in citation \# [16].

In addition, PMNs isolated from severe Mg-deficient rats at 3 weeks were shown to have $~ 50 \%$ lower NEP enzymatic activity compared to Mg-sufficient controls [22]. NEP activity in PMNs also remained low (40-50\%) even after 5 weeks of Mg deficiency. Western blot analysis revealed a substantial decrease in NEP protein content of Mg-deficient cardiac tissue ( $45 \%$ lower) at 5 weeks [21].

\subsection{NEP Modulates SP-Mediated Bioactivity and Neutrophil Activation During Mg Deficiency}

Severe Mg deficiency alone modestly raised circulating PMN basal superoxide production by $53 \%$ after 1 week [66]; in contrast, NEP inhibition by PR treatment in 1 week Mg-deficient rats led to a 3.9-fold elevation in basal PMN superoxide producing activity.

The cyclooxygenase (COX)-derived vasoactive mediators, prostaglandin $\mathrm{E}_{2}$ and $\mathrm{I}_{2}\left(\mathrm{PGE}_{2}\right.$ and $\left.\mathrm{PGI}_{2}\right)$, were upregulated during Mg deficiency. The effect of PR treatment on plasma levels of $\mathrm{PGE}_{2}$ metabolites (PGEM) was assessed in one-week severe Mg-deficient rats [66]. Mg deficiency alone caused a moderate, yet significant increase (1.6-fold) in PGEM levels, and PR treatment led to a further elevation (2.67-fold higher than control). Likewise, the depletion (7\%) of RBC GSH during one week of dietary $\mathrm{Mg}$ deficiency was not significant; however, PR treatment significantly enhanced the loss of GSH (21\%) 
compared to either the Mg deficiency alone or Mg-sufficient control groups [66]. Collectively, these findings suggested that enhancing plasma SP levels by inhibiting proteolytic SP degradation by NEP can increase in vivo oxidative stress.

\subsection{SP Receptor Upregulation Linked to Enhanced PMN Responsiveness During Mg Deficiency}

In light of our findings of elevated circulating SP levels during the early stage of Mg deficiency in rats, flow cytometry was used to estimate SP receptor presence in circulating white blood cells [16]. A multi-label FACS assay simultaneously using fluorophore-tagged anti-CD11b (PMNs) and indirectly-tagged SP receptor was developed. A significant elevation (greater than 2-fold) of SP receptor number was seen in PMNs after 2 weeks of Mg deficiency.

\subsection{SP-Induced Elevation in NO• Partially Mediates Deleterious Events During Mg Deficiency}

Severe $\mathrm{Mg}$ deficiency in rats caused substantial increases (1.7-to 2.5-fold) in plasma NO• oxidation products (nitrate + nitrite) during weeks 1 to 3 , suggesting the progressive activation of nitric oxide synthesis [35]. SP receptor blockade prevented $75 \%$ of this rise in plasma NO• oxidation products [67]. When 3 week Mg-deficient rats were treated with a non-specific nitric oxide synthase (NOS) inhibitor (L-NAME), it prevented much of the loss in RBC glutathione [35]. Moreover, treatment with L-NAME completely abolished the hemoglobin-NO signal detected by electron spin resonance (ESR) spectroscopy, confirming the presence of elevated plasma $\mathrm{NO} \bullet$ during $\mathrm{Mg}$ deficiency $[35,68]$. Dietary Mg deficiency also significantly induced iNOS (NOS2) protein expression in rat cardiac tissue [69]. Thus, $\mathrm{Mg}$ deficiency-induced neurogenic inflammation may trigger nitrosative stress that partially mediates deleterious events in this model.

\subsection{SP Receptor Blockade Protects Against Mg Deficiency-Induced Intolerance to Postischemic Stress}

$\mathrm{Mg}$ deficiency predisposed rat hearts to ex vivo ischemia/reperfusion (I/R) stress, and in vivo treatment with antioxidants prevented much of this enhanced injury $[12,13,70]$. Concurrent treatment with vitamin E improved recovery of postischemic function, and reduced lipid peroxidationderived alkoxyl radical production (via ESR spectroscopy and spin trapping), tissue injury (lactate dehydrogenase release), and tissue protein oxidation in $40 \mathrm{~min} \mathrm{I/R}$ hearts from Mg-deficient rats [12]. However, oxidative stress-related injury may be secondary to the prior in vivo actions of SP during $\mathrm{Mg}$ deficiency. Perfused I/R hearts from Mg-deficient rats treated with the SP receptor blocker, L-703,606, exhibited a significant improvement in postischemic functional recovery, whereas I/R-stressed control hearts did not significantly benefit [70]. Moreover, L-703,606 treatment of Mg-deficient rats led to significant reductions in postischemic tissue LDH loss, lipid hydroperoxide production, and alkoxyl radical formation [70]. Mg-deficient rat hearts produced substantially more NO• during reperfusion, and SP receptor blockade significantly reduced this heightened NO• production [67]. This further increase in NO• production from I/R-stressed Mg-deficient hearts is likely to involve prior SP-mediated enhancement of iNOS (NOS2) activity during Mg deficiency. Similar treatment in vivo did not provide additional protection to I/R-stressed control hearts with respect to the above parameters, and L-703,606 treatment acutely administered to perfusate during I/R stress proved ineffective [70]. Thus, SP receptor blockade in vivo inhibited SP-triggered inflammatory responses during dietary $\mathrm{Mg}$ deficiency and influenced the responses of the heart to subsequent postischemic stress.

\subsection{Acute Reduction in Perfusate Mg Modulates Neuropeptide and Cytokine Release from Normal Rat Hearts}

A link between neurogenic inflammation in vivo in the Mg-deficient rat and the subsequent lower myocardial tolerance to imposed postischemic stress ex vivo has been established [70]. We next examined the cardiac neuropeptide (NP) release process with respect to the acute sensitivity of the Mg-gated NMDA receptor complex to declining extracellular Mg levels, and how this may impact inflammatory cytokine release. Mg-normal working rat hearts were perfusion stabilized for $15 \mathrm{~min}$ (baseline) with oxygenated physiologic KHB (5.0 mM glucose, $1.25 \mathrm{mM} \mathrm{CaCl}_{2}$ and $1.2 \mathrm{mM}$ 
$\mathrm{MgSO} 4$ ) prior to $10 \mathrm{~min}$ perfusion intervals with $0.8,0.6,0.3$ or $0.0 \mathrm{mM} \mathrm{MgSO} 4$-containing perfusate. The chosen $\mathrm{Mg}$ concentrations were similar to the hypomagnesemic range experienced by rats placed on the MgD diets [23]. Progressive decreases in cardiac work (CW: 91 to 38\% decline) were associated with reductions in perfusate $\mathrm{Mg}$ (Figure 7). While there were modest declines in LV systolic pressure [LVSP] and coronary flow rate [CFR], most of the effect on CW (calculated as [cardiac output] $x$ LVSP) could be attributed to substantial reductions in cardiac output (aortic output + CFR in $\mathrm{ml} / \mathrm{min}$ ), especially at $[\mathrm{Mg}]$ below $0.6 \mathrm{mM}$. Changes in hemodynamic parameters resulting from $10 \mathrm{~min}$ perfusion with reduced $\mathrm{Mg}$ were reversible; each recovered toward baseline values upon restoration of $1.2 \mathrm{mM}$ Mg-containing perfusate.

\section{Acute Reduction of Perfusate Mg Alters Hemodynamic Properties of Normally-Perfused Working Rat Hearts}

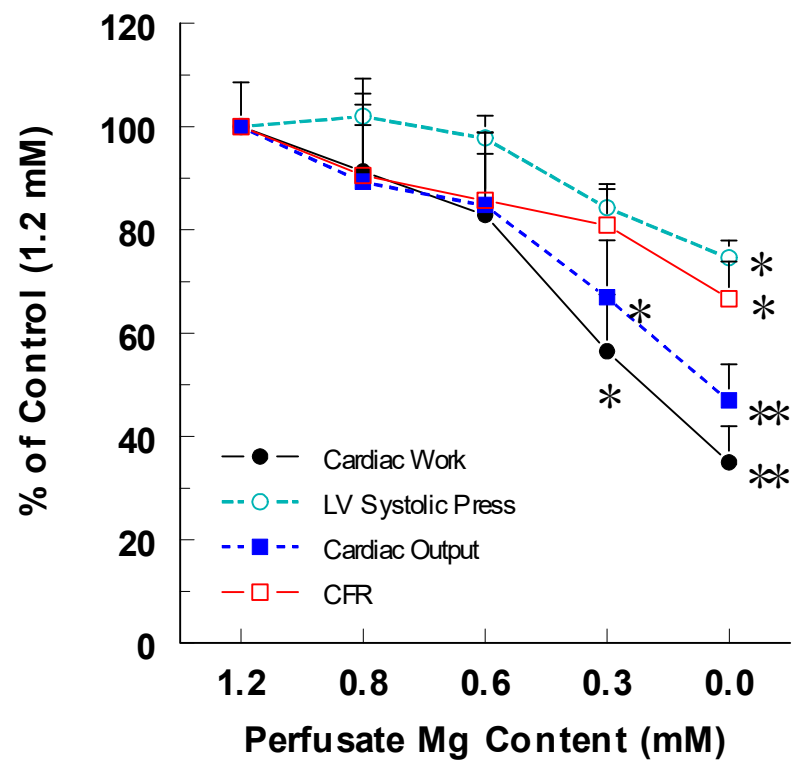

Figure 7. Acute reduction in perfusate magnesium concentration alters hemodynamic properties of normally perfused working rat hearts. Hearts from 3 week magnesium normal (control or Mg-sufficient) rats were perfused in working mode for 15 min with oxygenated physiologic Krebs-Henseleit buffer containing $1.25 \mathrm{mM} \mathrm{CaCl} 2,5 \mathrm{mM}$ glucose and $1.2 \mathrm{mM} \mathrm{MgSO}$. After stabilization and recording baseline functional/hemodynamics indices, hearts were immediately exposed to one of the reduced $\mathrm{Mg}$ $(0.8,0.6,0.3$, or $0.0 \mathrm{mM})$-containing perfusates for $10 \mathrm{~min}$, and functional/hemodynamics parameters were recorded during the final $5 \mathrm{~min}$. Values are means $\pm \mathrm{SE}$ of $3-5$ rat hearts $/ \mathrm{Mg}$ concentration. * and ${ }^{* *} p<0.05$ and 0.01 vs. Ctl $(1.2 \mathrm{mM} \mathrm{Mg})$.

Heart effluent samples were collected prior to reduced Mg exposure (baseline: Table 1) and then every $\min$ for $5 \mathrm{~min}$ during each reduced $\mathrm{Mg}$ period for subsequent analyses of inflammatory mediators. Average neuropeptide (substance P [SP], vasointestinal peptide [VIP], neuropeptide Y [NPY], calcitonin gene-related peptide [CGRP]) and cytokine (IL-1, IL-6, TNF $\alpha$ ) levels were determined by antigen capture Chem-ELISA. The findings suggest that the NMDA receptor-mediated release of neuropeptides is sensitive to acute changes in extracellular Mg levels. While all examined NPs displayed small (16-25\%), yet significant elevations in their effluent levels during heart exposure to $0.8 \mathrm{mM} \mathrm{Mg}$, SP was the only NP which exhibited a progressive increase (16-60\%) as perfusate $\mathrm{Mg}$ further declined (Figure 8A); this suggests that the receptor-mediated release of this NP, unlike the others, is highly sensitive to variations in external $\mathrm{Mg}$ content. Likewise, as perfusate $\mathrm{Mg}$ fell, the same hearts also exhibited progressive increases in all examined inflammatory cytokines (Figure 8B: IL-1: 31-172\%; IL-6: 37-121\%; TNF $\alpha$ : 27-106\%), implicating a link between excessive SP release and the enhanced 
inflammatory response. These studies support the concept that mild to moderate hypomagnesemia may invoke significant pro-inflammatory responses.

Table 1. Baseline Levels of Inflammatory Mediators Released into Effluent from Perfused Control (MgS) Rats Hearts.

\begin{tabular}{cc}
\hline Inflammatory Mediator & $\begin{array}{c}\text { MgS Heart Effluent Levels } \\
{[\mathrm{pg} / \mathrm{g} \text { prot/ml] per gm Wet wt Tissue }}\end{array}$ \\
\hline IL-1 & $5.03 \pm 0.23$ \\
\hline IL-6 & $3.13 \pm 0.26$ \\
\hline TNF $\alpha$ & $6.74 \pm 0.22$ \\
\hline SP & $5.09 \pm 0.21$ \\
\hline CGRP & $4.33 \pm 0.20$ \\
\hline VIP & $2.95 \pm 0.22$ \\
\hline NY & $3.62 \pm 0.52$ \\
\hline
\end{tabular}
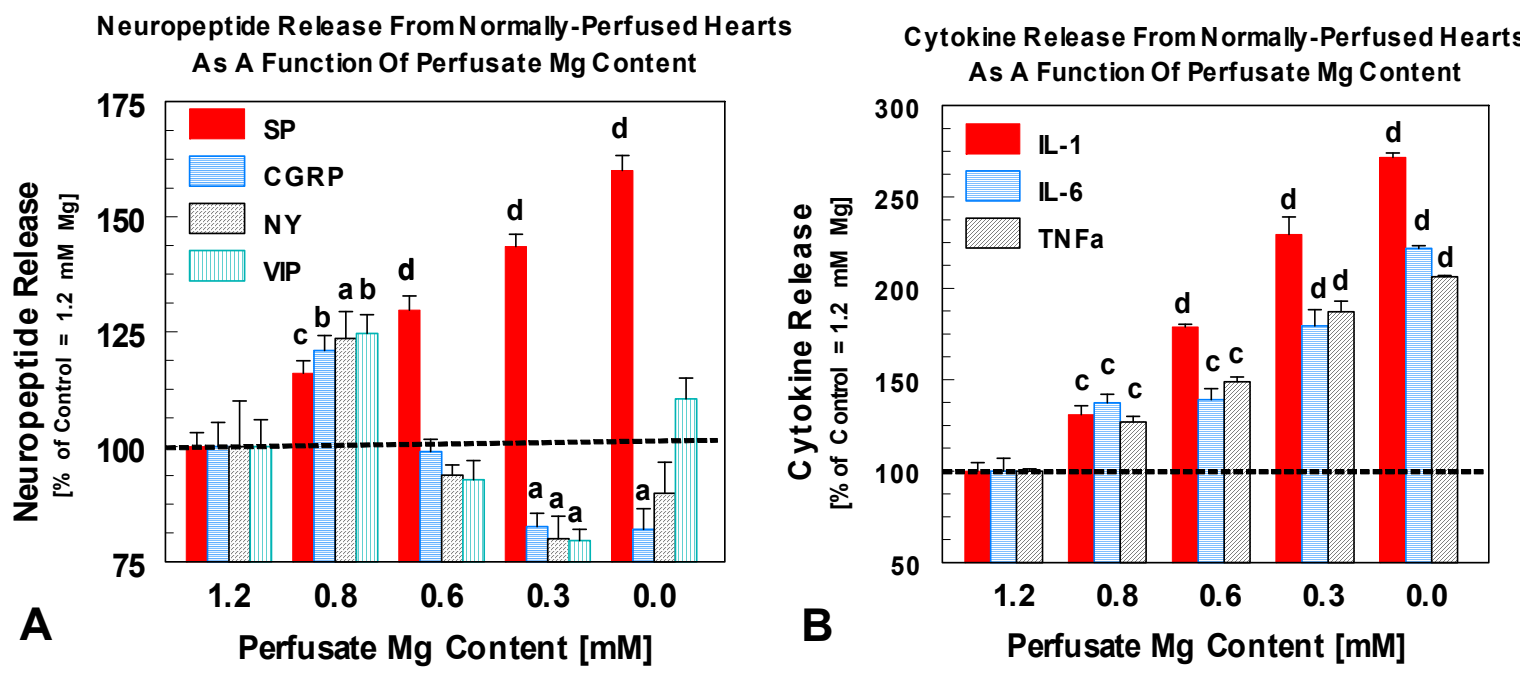

Figure 8. Acute neuropeptide (A: NP) and inflammatory cytokine (B) release from normally-perfused rat hearts as a function of perfusate $\mathrm{Mg}$ concentration. Hearts from $\mathrm{MgS}$ rats (means $\pm \mathrm{SE}$ of $4-5$ ) were exposed to $5 \mathrm{~min}$ perfusion intervals at the described $[\mathrm{Mg}]$, effluent was collected each $\mathrm{min}$, and average NP (A) and cytokine (B) levels were determined by HPCE/ELISA. SP = substance P; CGRP = calcitonin gene-related peptide; NY = neuropeptide $\mathrm{Y} ; \mathrm{VIP}=$ vasoactive intestinal peptide; IL-1 = interleukin-1; IL-6 = interleukin-6; and TNF $\alpha=$ tumor necrosis factor alpha. a,b,c,d $=p<0.05,0.02,0.01$ and 0.001 vs. control, respectively.

Perfused working heart model was described [12]. Cannulated hearts were perfused with physiologic Krebs-Henseleit buffer containing $1.25 \mathrm{mM}$ calcium chloride, $1.2 \mathrm{mM}$ magnesium sulfate, and $5 \mathrm{mM}$ glucose. After $15 \mathrm{~min}$ of stabilization, baseline effluent samples were collected for subsequent analyses of neuropeptides and inflammatory cytokines by HPCE/ELISA. Values are means $\pm \mathrm{SE}$ of 4-5 rat hearts. IL-1 = interleukin-1; IL-6 = interleukin-6; TNF $\alpha=$ tumor necrosis factor alpha; SP = substance $\mathrm{P} ; \mathrm{CGRP}=$ calcitonin gene-related peptide; $\mathrm{NY}=$ neuropeptide $\mathrm{Y}$; VIP = vasoactive intestinal peptide. 


\section{Materials and Methods}

\subsection{Chemicals and Experimental Agents}

Reagents and solvents were from Thermo Fisher Scientific (Washington, DC, USA) or Millipore Sigma (St. Louis, MO, USA). Alkaline phosphatase used for antibody labeling was purchased from Millipore Sigma. Specific antibodies directed against neuropeptides were from Chemicon International, Inc. (Temecula, CA, USA), and lyophilized neuropeptides from Bachem Bioscience Inc. (King of Prussia, PA, USA). Heavy metal levels in all solutions were assessed by atomic absorption using a Shimadzu flame emission spectrophotometer and were below the limits of detection. The substance $\mathrm{P}$ receptor blocker, L-703,606 ((cis)-2-(diphenylmethyl)-N-[(2-iodophenyl)methyl]-1-azabicyclo [2.2.2]octan-3-amine, oxalate salt) was from Research Biochemicals International (Natick, MA) and was prepared as 3 or 5 week continuous-release subcutaneous pellets $(1.0 \mathrm{mg} / \mathrm{kg} / \mathrm{day}$, or placebo) by Innovative Research Of America (Sarasota, Fl, USA). Phosphoramidon (PR: neutral endopeptidase (NEP) inhibitor: $5 \mathrm{mg} / \mathrm{kg} /$ day, one-week s.c. pellet), and the N-methyl-D-aspartate (NMDA) receptor inhibitor, dizolcipine maleate (MK-801: $0.5 \mathrm{mg} / \mathrm{kg} /$ day, 3 week s.c. pellet) were each from Millipore Sigma and pellets were prepared by Innovative Research Of America.

\subsection{Animal Assurance}

Animal experiments were guided by the principles for the care and use of laboratory animals as recommended by the US Department of Health and Human Services and approved by The George Washington University (GWU) Animal Care and Use Committee (approved IACUC \# A156; initial approval September 2009 and extended).

\subsection{Dietary Model}

Age-matched male Sprague-Dawley rats (150-175 g) were purchased from Hilltop Lab Animals, Inc. (Scottdale, PA) through the GWU Animal Research Facility (ARF). After 1 week quarantine, rats were place on a low-magnesium diet $\left(\mathrm{Mg}\right.$ deficient $[\mathrm{MgD}]=\mathrm{Mg}_{9}=1.8 \mathrm{mmol} \mathrm{Mg} / \mathrm{kg}$ feed $=$ $9 \%$ recommended daily allowance [RDA]), or on this diet supplemented with an additional 20.0 mmol Mg oxide/ $\mathrm{kg}$ (control or $\mathrm{Mg}$ sufficient $[\mathrm{MgS}]=\mathrm{Mg}_{100}=100 \%$ RDA) for up to 5 weeks [22,24]. The US National Research Council's RDA for normal rat maintenance and growth was estimated to be 500 ppm [23], and our $\mathrm{Mg}_{100}$ diet contained 509 ppm. Diet composition (Envigo-Teklad Laboratory, Madison, WI USA) contained extracted casein as the diet base, essential vitamins and nutrients, and was well tolerated; animal housing conditions within the ARF were described [23].

\subsection{Blood Collection/Preparation}

Aseptic tail blood collection $(\sim 0.5 \mathrm{~mL})$ from anaesthetized rats $(2 \%$ isoflurane, EZ Anesthesia Chamber with nose cone, E-Z Systems, Palmer, PA) [71] was conducted 2-3 times per week for up to 5 weeks in sterile microtainer plasma separator tubes containing aprotinin (protease inhibitor, Millipore Sigma, St. Louis MO, USA) and heparin to give blood concentrations of 0.016 and 10.74 units/mL, respectively. Following centrifugation $(12,000 \mathrm{rpm}$, for $2 \mathrm{~min}$, RT; IDEXX StatSpin VT, Iris International, Inc., Westwood, MA, USA), plasma samples were used for assessment of $\mathrm{Mg}$ and substance P levels. At sacrifice, blood samples were collected $(\sim 8 \mathrm{~mL}$ in aprotinin plus heparin containing BD vacutainer SST tubes) from anaesthetized, heparinized rats $(0.35-0.45 \mathrm{~mL} 358$ units $/ \mathrm{mL}$ heparin in $0.9 \% \mathrm{NaCl}$, i.p.) by cardiac puncture, and centrifuged (3500 rpm, for $10 \mathrm{~min}, \mathrm{RT}$ ). Sacrifice whole blood samples were processed for neutrophil isolation and assessed for superoxide anion production, whereas sacrifice plasma samples were assayed for 8-isoprostane levels. 


\subsection{Plasma Magnesium}

Plasma Mg was determined by atomic absorption flame emission spectroscopy (wavelength = $285.2 \mathrm{~nm}$ ) using an AA-6200 Shimadzu spectrophotometer (Columbia, MD, USA) [71]. Plasma were acidified and diluted 1:50 fold in 2\% nitric acid. Values were estimated from a standard curve.

\subsection{Plasma Substance P}

A competitive binding, 96 well colorimetric ELISA assay kit from R\&D Systems (Minneapolis, MN, USA) was used to assess plasma SP levels [1,24]. SP in plasma was diluted 1:1 (to $50 \mu \mathrm{L}$ ) and allowed to compete with a fixed amount of horseradish peroxidase-labeled SP for murine monoclonal antibody sites. The concentration of SP was inversely proportional to color development and absorption read at $450 \mathrm{~nm}$ using a VersaMax microplate reader (Molecular Devices, Sunnyvale, CA, USA) with background subtraction at $540 \mathrm{~nm}$. Mean values $\pm \mathrm{SE}$ for each group of 5 rats were obtained and represent changes in plasma SP levels compared to time-paired controls. After baseline subtraction, area integration of weekly dietary time intervals allowed determination of total plasma SP levels at those intervals. The average baseline control rat plasma SP level $(n=15)$ was $447.6 \pm 31 \mathrm{pg} / \mathrm{mL}$.

\subsection{Perfusate Neuropeptides and Inflammatory Cytokines}

After collecting baseline effluent samples (1.2 mM MgSO4-containing Krebs-Henseleit buffer), effluent from isolated control rat hearts perfused acutely with reduced magnesium-containing perfusate $(0.8,0.6,0.3,0.0 \mathrm{mM} \mathrm{Mg}$ ) were collected every minute for $5 \mathrm{~min}$ in EDTA-containing (10 $\mu \mathrm{L}$ of $15 \%)$ tubes place on ice, and stored at $-80{ }^{\circ} \mathrm{C}$. Neuropeptide (SP, CGRP, NY, VIP) and inflammatory cytokine (IL-1, IL-6, TNF $\alpha$ ) concentrations were determined by CHEM-ELISA using specific alkaline phosphatase-labeled antibodies directed against each mediator [23,70]. Assays were run on fractions after separation using an ISCO 3140 high-performance capillary electrophoresis (HPCE) system [18]. Baseline neuropeptide and cytokine levels in perfused control rat heart effluent are shown in Table 1.

\subsection{Red Blood Cell Glutathione}

Total cellular glutathione (GSH + GSSG) levels were assessed in packed red blood cell samples collected in heparinized tubes at dietary week 3 or $5[22,68]$. Hemolyzed samples were diluted 50 -fold and acidified with 5\% 5-sulfosalicylic acid to preserve GSH. The "cyclic method" was used which combines the colorimetric reaction of 5,5'-dithiobis-(2-nitrobenzoic acid) (DTNB) with the enzymatic specificity of GSSG reductase, and the reaction was spectrometrically followed (412 nm) with (for GSSG) or without (for GSH+GSSG) the inclusion of $2 \%$ vinyl pyridine.

\subsection{Plasma 8-Isoprostane}

Levels of 8-isoprostane at dietary week 5 were determined on sacrifice plasma samples diluted 5and 10-fold by ELISA assay buffer (kit from Cayman Chemical, Ann Arbor, MI, USA). Free 8-isoprostane levels were estimated according to standard curves [71].

\subsection{Neutrophil Basal and Stimulated Superoxide Generation}

At 5 weeks, neutrophils from $3 \mathrm{~mL}$ whole blood sacrifice samples were obtained from each rat using a step-gradient centrifugation method [71]. Superoxide anion production from neutrophils $\left(0.7-1 \times 10^{6} / \mathrm{mL}\right)$ without (basal) or with (stimulated) phorbol myristate acetate (PMA, $100 \mathrm{ng} / \mathrm{mL}$ ) was determined in a sodium phosphate buffer ( $\mathrm{pH}$ 7.6) containing $1 \mathrm{mM} \mathrm{MgCl}, 1 \mathrm{mM} \mathrm{CaCl}_{2}, 5 \mathrm{mM}$ glucose and $75 \mu \mathrm{M}$ cytochrome $\mathrm{c} \pm 50 \mu \mathrm{g}$ superoxide dismutase (SOD). Neutrophil superoxide-generating activity was measured as SOD-inhibitable reduction in cytochrome $\mathrm{c}$ using the extinction coefficient: $\mathrm{E} 550=2.1 \times 10^{4} \mathrm{M}^{-1} \mathrm{~cm}^{-1}$. 


\subsection{Non-Invasive Transthoracic Echocardiography}

Anesthetized rats ( $2 \%$ isoflurane, EZ Anesthesia Chamber with nose cone) received echocardiography at 3 and 5 weeks during treatment using a GE VingMed System Five Echocardiogram System $[2,22,24,71]$. Both rectal temperature $\left(35.9-37.5^{\circ} \mathrm{C}\right)$ and heart rate were monitored while rats were placed on a warming platform with paws taped down to limit motion during imaging. A sterile eye lubricant was applied to prevent eye drying during echocardiography. Hair over the thorax was removed using an electric clipper, followed by a depilatory cream $(<2$ min exposure, then wiped and rinsed clean). Rats were imaged using a $10 \mathrm{MHz}$ probe for $20 \mathrm{~min}$ at a $3 \mathrm{~cm}$ image depth, allowing for both cardiac functional and structural evaluation. Left ventricular (LV) systolic function was measured as \% fractional shortening (\% FS) using M-mode imaging and left ventricular ejection fraction (LVEF) was calculated based on M-mode measurements. The measured anatomical parameters included LV posterior wall thickness in diastole or systole (LVPWd or s), interventricular septum wall dimension in diastole or systole (IVSs or s), and LV chamber diameter in diastole or systole (LVDd or s) to evaluate the presence of dilated cardiomyopathy and reduced cardiac function. Aortic pressure maximum (AoPmax) was assessed and aortic and pulmonary artery diameters were measured to calculate stroke volumes. Spectral Doppler velocity measurements were used for pulmonic and aortic outflows for calculation of cardiac output (CO) and for mitral valve inflows to assess ventricular diastolic function (mitral valve $\mathrm{E}$ and $\mathrm{A}$ wave velocities and the $\mathrm{E} / \mathrm{A}$ ratio [early/late $[\mathrm{A}=$ atrial] ventricular filling velocity]). After echocardiography, rats were placed in room air and observed until fully recovered.

\subsection{Perfused Heart Model}

The working rat heart model was described previously [23]. Cannulated hearts (non-paced) were perfused (non-recirculating, $95 \% \mathrm{O}_{2}: 5 \% \mathrm{CO}_{2}, 37^{\circ} \mathrm{C}$, pH 7.4) with physiologic Krebs-Henseleit buffer (KHB) containing $1.25 \mathrm{mM}$ calcium chloride, $1.2 \mathrm{mM}$ magnesium sulfate, and supplemented with $5 \mathrm{mM}$ glucose. After $15 \mathrm{~min}$ of stabilization, baseline hemodynamic parameters were measured and effluent samples for biochemical analyses were taken, followed by $10 \mathrm{~min}$ perfusion with one of the designated reduced $\mathrm{Mg}(0.8,0.6,0.3$, or $0.0 \mathrm{mM})$ perfusates. Coronary effluent was collected every minute for the first $5 \mathrm{~min}$ and saved for subsequent analyses of neuropeptides and inflammatory cytokines. During the final $5 \mathrm{~min}$, hemodynamic parameter measurements (cardiac pressure-volume work, cardiac output, coronary flow rate and left ventricular peak systolic pressure via P23 Gb Statham transducers) were repeated to assess changes versus baseline values.

\subsection{Statistical Approaches}

Power analysis was used to determine minimal animal number needed per group to achieve statistical differences. Based on a 7-8\% coefficient of variation, a 15-17\% detectability threshold, an $\alpha=$ 0.05 and $\beta=0.2$, five animals per group were required. Data are means \pm SE and were checked by $F$-test for equality of groups' variation. The two-tailed Student's $t$-test was used to evaluate statistical differences and selected data were analyzed by one-way ANOVA followed by a Tukey test. Significance level was considered at $p<0.05$.

\section{Conclusions}

SP-mediated inflammation occurs in rodents during diet-induced hypomagnesemia, and this neuropeptide triggers much of the subsequent inflammatory, oxidative, and nitrosative events leading to development of cardiac dysfunction, cardiomyopathy, and the loss of myocardial tolerance to imposed ischemia/reperfusion stress. Treatments which altered neuronal SP release (NMDA receptor/channel blockade, or varying dietary Mg intake), enhanced SP bioavailability (NEP inhibition), reduced SP bioactivity (SP receptor blockade), or limited oxidative/nitrosative stress injury (antioxidants, nitric oxide synthase inhibitors) had direct impact on the pathology associated with this mineral 
deficiency. Moderate Mg deficiency in rodents produced SP-mediated inflammation even at levels of hypomagnesemia comparable [23] to those encountered in various clinical conditions [3,5,72]. This was further supported by findings that acute reduction in perfusate $\mathrm{Mg}$ content modulated NP and inflammatory cytokine release from perfused control rat hearts. Of all the NPs examined, myocardial SP release was the most sensitive to changes in extracellular $\mathrm{Mg}$, which would be consistent with control at the Mg-gated neuronal NMDA receptor channel complex. This is also supported by the fact that the heart is highly innervated with C fibers [45] which are enriched with SP and other NPs and may be a primary source of released neuropeptides. Moreover, the progressive increase in SP release was mirrored by the release profiles for inflammatory cytokines; this suggests a direct association between SP and the severity of inflammation/oxidative stress in hearts from Mg-normal animals. Thus, a similar extracellular [Mg]-modulated neuronal release mechanism may be responsible for inflammation/oxidative stress in both the acute perfused rat heart model and during the early weeks of Mg deficiency. The persistence of elevated SP during prolonged hypomagnesemia may be a partial consequence of non-neuronal sources and/or inhibition of enzymatic degradation of SP. Given the fact that co-existing hypomagnesemia is prevalent in several experimental and clinical inflammatory conditions [1-7], use of SP receptor blockers, intervention with magnesium supplements, or ensuring proper dietary magnesium intake should lessen the potential pathology associated with Mg deficiency.

Author Contributions: Conceptualization, J.H.K., I.T.M. and W.B.W.; data curation, J.H.K., I.T.M. and J.J.C.; formal analysis, J.H.K., I.T.M., J.J.C. and T.M.P.; funding acquisition, J.H.K., I.T.M., J.J.C. and W.B.W.; investigation, J.H.K., I.T.M., J.J.C. and C.F.S.; methodology, J.H.K., I.T.M., J.J.C., C.F.S. and T.M.P.; project administration, J.H.K., I.T.M. and W.B.W.; supervision, J.H.K. and I.T.M.; validation, J.H.K., I.T.M. and J.J.C.; visualization, J.H.K., I.T.M. and C.F.S.; writing—original draft, J.H.K.; writing—review and editing, J.H.K., I.T.M., J.J.C., C.F.S., T.M.P. and W.B.W. All authors have read and agreed to the published version of the manuscript.

Funding: This study was supported by USPHS grants NIH RO1-HL-62282-09, 1R21NR012649-01 and 1R21HL108311-01.

Conflicts of Interest: The authors declare no conflict of interest. The sponsors had no role in study design, in the collection, analyses, or interpretation of data, in the writing of the manuscript, and in the decision to publish results.

\section{References}

1. Mak, I.T.; Kramer, J.H.; Chmielinska, J.J.; Spurney, C.F.; Weglicki, W.B. EGFR-TKI, erlotinib, causes hypomagnesemia, oxidative stress, and cardiac dysfunction: Attenuation by NK-1 receptor blockade. J. Cardiovasc. Pharmacol. 2015, 65, 54-61. [CrossRef] [PubMed]

2. Mak, I.T.; Chmielinska, J.J.; Spurney, C.F.; Weglicki, W.B.; Kramer, J.H. Combination ART-Induced Oxidative/Nitrosative Stress, Neurogenic Inflammation and Cardiac Dysfunction in HIV-1 Transgenic (Tg) Rats: Protection by Mg. Int. J. Mol. Sci. 2018, 19, 2409. [CrossRef] [PubMed]

3. Seelig, M. Cardiovascular consequences of magnesium deficiency and loss: Pathogenesis, prevalence and manifestations-Magnesium and chloride loss in refractory potassium repletion. Am. J. Cardiol. 1989, 63, G4-G21. [CrossRef]

4. Cheungpasitporn, W.; Thongprayoon, C.; Qian, Q. Dysmagnesemia in Hospitalized Patients: Prevalence and Prognostic Importance. Mayo Clin. Proc. 2015, 90, 1001-1010. [CrossRef] [PubMed]

5. Altura, B.M.; Altura, B.T. New perspective on the role of $\mathrm{Mg}$ in the pathophysiology of the cardiovascular system. 1. Clin. Asp. Magnes 1985, 4, 226-244.

6. Severino, P.; Netti, L.; Mariani, M.V.; Maraone, A.; D'Amato, A.; Scarpati, R.; Infusino, F.; Pucci, M.; LaValle, C.; Maestrini, V.; et al. Prevention of Cardiovascular Disease: Screening for Magnesium Deficiency. Cardiol. Res. Pract. 2019, 2019, 4874921. [CrossRef]

7. Heggtveit, H.A.; Herman, L.; Mishra, R.K. Cardiac necrosis and calcification in experimental magnesium deficiency. a light and electron microscopic study. Am. J. Pathol. 1964, 45, 757-782.

8. Weglicki, W.B.; Bloom, S.; Cassidy, M.M.; Freedman, A.M.; Atrakchi, A.H.; Dickens, B.F. Antioxidants and the cardiomyopathy of Mg-deficiency. Am. J. Cardiovasc. Pathol. 1992, 4, 210-215. 
9. Itokawa, Y. Tissue minerals of magnesium-deficient rats with thiamine deficiency and excess. Magnesium 1987, 6, 48-54.

10. Chang, C.; Varghese, P.J.; Downey, J.; Bloom, S. Magnesium deficiency and myocardial infarct size in the dog. J. Am. Coll. Cardiol. 1985, 5, 280-289. [CrossRef]

11. Borchgrevink, P.C.; Jynge, P. Acquired magnesium deficiency and myocardial tolerance to ischemia. J. Am. Coll. Nutr. 1987, 6, 355-363. [CrossRef] [PubMed]

12. Kramer, J.H.; Mišík, V.; Weglicki, W.B. Magnesium deficiency potentiates free radical production associated with post ischemic injury to rat hearts: Vitamin E affords protection. Free Rad. Biol. Med. 1994, 16, 713-723. [CrossRef]

13. Weglicki, W.B.; Phillips, T.M.; Mak, I.T.; Cassidy, M.M.; Dickens, B.F.; Stafford, R.; Kramer, J.H. Cytokines, neuropeptides, and reperfusion injury during magnesium deficiency. Ann. N.Y. Acad. Sci. 1994, 723, $246-257$. [CrossRef]

14. Kharb, S.; Singh, V. Magnesium deficiency potentiates free radical production associated with myocardial infarction. J. Assoc. Physicians India 2000, 48, 484-485. [PubMed]

15. Weglicki, W.B.; Phillips, T.M.; Cassidy, M.M.; Mak, I.T.; Dickens, B.F.; Stafford, R.E.; Kramer, J.H. Pro oxidant stress in Mg Deficiency: Role of neuropeptides and cytokines. In The Oxygen Paradox; Davies, K.J.A., Ursini, F., Eds.; Cleop University Press: Padova, Italy, 1995; pp. 773-782.

16. Weglicki, W.B.; Mak, I.T.; Chmielinska, J.J.; Tejero-Taldo, M.I.; Komarov, A.M.; Kramer, J.H. The role of magnesium deficiency in cardiovascular and intestinal inflammation. Magnes. Res. 2010, 23, S199-S206. [CrossRef] [PubMed]

17. Weglicki, W.B.; Mak, I.T.; Stafford, R.E.; Dickens, B.F.; Cassidy, M.M.; Phillips, T.M. Neurogenic peptides and the cardiomyopathy of magnesium-deficiency: Effects of substance P-receptor inhibition. Mol. Cell. Biochem. 1994, 130, 103-109. [CrossRef] [PubMed]

18. Weglicki, W.B.; Mak, I.T.; Phillips, T.M. Blockade of cardiac inflammation in Mg2+ deficiency by substance P receptor inhibition. Circ. Res. 1994, 74, 1009-1013. [CrossRef]

19. Weglicki, W.B.; Phillips, T.M. Pathobiology of magnesium deficiency: A cytokine/neurogenic inflammation hypothesis. Am. J. Physiol. Integr. Comp. Physiol. 1992, 263, R734-R737. [CrossRef]

20. Weglicki, W.B.; Mak, I.T.; Kramer, J.H.; Dickens, B.F.; Cassidy, M.M.; Stafford, R.E.; Phillips, T.M. Role of free radicals and substance $\mathrm{P}$ in magnesium deficiency. Cardiovasc. Res. 1996, 31, 677-682. [CrossRef]

21. Weglicki, W.B.; Chmielinska, J.J.; Tejero-Taldo, I.; Kramer, J.H.; Spurney, C.F.; Viswalingham, K.; Lu, B.; Mak, I.T. Neutral endopeptidase inhibition enhances substance P mediated inflammation due to hypomagnesemia. Magnes. Res. 2009, 22, 167S-173S. [CrossRef]

22. Mak, I.T.; Chmielinska, J.J.; Kramer, J.H.; Spurney, C.F.; Weglicki, W.B. Loss of neutral endopeptidase activity contributes to neutrophil activation and cardiac dysfunction during chronic hypomagnesemia: Protection by substance P receptor blockade. Exp. Clin. Cardiol. 2011, 16, 121-124. [PubMed]

23. Kramer, J.H.; Mak, I.T.; Phillips, T.M.; Weglicki, W.B. Dietary Magnesium Intake Influences Circulating Pro-Inflammatory Neuropeptide Levels and Loss of Myocardial Tolerance to Postischemic Stress. Exp. Biol. Med. 2003, 228, 665-673. [CrossRef] [PubMed]

24. Kramer, J.H.; Spurney, C.; Iantorno, M.; Tziros, C.; Mak, I.-T.; Tejero-Taldo, M.I.; Chmielinska, J.J.; Komarov, A.M.; Weglicki, W.B. Neurogenic inflammation and cardiac dysfunction due to hypomagnesemia. Am. J. Med. Sci. 2009, 338, 22-27. [CrossRef] [PubMed]

25. Satake, H.; Kawada, T. Overview of the primary structure, tissue-distribution, and functions of tachykinins and their receptors. Curr. Drug Targets 2006, 7, 963-974. [CrossRef]

26. Ho, W.-Z.; Douglas, S.D. Substance P and neurokinin-1 receptor modulation of HIV. J. Neuroimmunol. 2004, 157, 48-55. [CrossRef]

27. Almeida, T.A.; Rojo, J.; Nieto, P.M.; Pinto, F.M.; Hernández, M.; Martin, J.D.; Candenas, M.L. Tachykinins and Tachykinin Receptors: Structure and Activity Relationships. Curr. Med. Chem. 2004, 11, 2045-2081. [CrossRef]

28. Datar, P.; Srivastava, S.; Coutinho, E.; Govil, G. Substance P: Structure, function, and therapeutics. Curr. Top. Med. Chem. 2004, 4, 75-103. [CrossRef]

29. Saria, A. The tachykinin NK1 receptor in the brain: Pharmacology and putative functions. Eur. J. Pharmacol. 1999, 375, 51-60. [CrossRef] 
30. Derose, V.; A Robbins, R.; Snider, R.M.; Spurzem, J.R.; Thiele, G.M.; I Rennard, S.; Rubinstein, I. Substance P increases neutrophil adhesion to bronchial epithelial cells. J. Immunol. 1994, 152, 1339-1346.

31. Kubes, P.; Kanwar, S.; Niu, X.; Gaboury, J.P. Nitric oxide synthesis inhibition induces leukocyte adhesion via superoxide and mast cells. FASEB J. 1993, 7, 1293-1299. [CrossRef]

32. Hartung, H.P.; Toyka, K.V. Activation of macrophages by substance P: Induction of oxidative burst and thromboxane release. Eur. J. Pharmacol. 1983, 89, 301-305. [CrossRef]

33. Persson, M.G.; Hedqvist, P.; Gustafsson, L.E. Nerve induced tachykinin mediated vasodilation in skeletal muscle is dependent on nitric oxide formation. Eur. J. Pharmacol 1991, 205, 295-301. [CrossRef]

34. Hafström, I.; Gyllenhammar, H.; Palmblad, J.; Ringertz, B. Substance P activates and modulates neutrophil oxidative metabolism and aggregation. J. Rheumatol. 1989, 16, 1033-1037. [PubMed]

35. Mak, I.T.; Dickens, B.F.; Komarov, A.M.; Phillips, T.M.; Weglicki, W.B. Activation of the neutrophil and loss of plasma glutathione during Mg-deficiency-Modulation effect by NOS inhibition. Mol. Cell Biochem. 1997, 176, 35-39. [CrossRef] [PubMed]

36. Rude, R.K.; Singer, F.R.; Gruber, H.E. Skeletal and hormonal effects of magnesium deficiency. J. Am. Coll. Nutr. 2009, 28, 131-141. [CrossRef]

37. Vink, R.; Donkin, J.J.; Cruz, M.I.; Nimmo, A.J.; Cernak, I. A substance P antagonist increases brain intracellular free magnesium concentration after diffuse traumatic brain injury in rats. J. Am. Coll. Nutr. 2004, 23, 538S-540S. [CrossRef]

38. Grimaldi, B.L. The central role of magnesium deficiency in Tourette's syndrome: Causal relationships between magnesium deficiency, altered biochemical pathways and symptoms relating to Tourette's syndrome and several reported comorbid conditions. Med. Hypotheses 2002, 58, 47-60. [CrossRef]

39. Feickert, M.; Burckhardt, B.B. Substance P in cardiovascular diseases-A bioanalytical review. Clin. Chim. Acta 2019, 495, 501-506. [CrossRef]

40. Nordmann, R.; Ribière, C.; Rouach, H. Implication of free radical mechanisms in ethanol-induced cellular injury. Free Radic. Biol. Med. 1992, 12, 219-240. [CrossRef]

41. Iversen, L.L.; Emson, P.C.; Lee, C.M.; Gilbert, R.F.; Hunt, S. Regulation of neuropeptide release. Proc. R. Soc. London Ser. B Biol. Sci. 1980, 210, 91-111. [CrossRef]

42. Catterall, W.A. Structure and Modulation of Na+and Ca2+Channels. Ann. N.Y. Acad. Sci. 1993, 707, 1-19. [CrossRef] [PubMed]

43. Brasier, A.R. The NF-kB Regulatory Network. Cardiovasc. Toxicol. 2006, 6, 111-130. [CrossRef]

44. Furness, J.B.; Papka, R.E.; Della, N.G.; Costa, M.; Eskay, R.L. Substance P-like immunoreactivity in nerves associated with the vascular system of guinea-pigs. Neuroscience 1982, 7, 447-459. [CrossRef]

45. Furness, J.; Costa, M.; Papka, R.E.; Della, N.G.; Murphy, R.; Delia, N.G. Neuropeptides Contained in Peripheral Cardiovascular Nerves. Clin. Exp. Hypertens. Part A Theory Pr. 1984, 6, 91-106. [CrossRef] [PubMed]

46. Coggeshall, R.E.; Carlton, S.M. Ultrastructural analysis of NMDA, AMPA, and kainate receptors on unmyelinated and myelinated axons in the periphery. J. Comp. Neurol. 1998, 391, 78-86. [CrossRef]

47. Lin, Y.J.; Bovetto, S.; Carver, J.M.; Giordano, T. Cloning of the cDNA for the human NMDA receptor NR2C subunit and its expression in the central nervous system and periphery. Mol. Brain Res. 1996, 43, 57-64. [CrossRef]

48. Mishina, M.; Mori, H.; Araki, K.; Kushiya, E.; Meguro, H.; Kutsuwada, T.; Kashiwabuchi, N.; Ikeda, K.; Nagasawa, M.; Yamazaki, M.; et al. Molecular and Functional Diversity of the NMDA Receptor Channel. Ann. N.Y. Acad. Sci. 1993, 707, 136-152. [CrossRef]

49. Masu, M.; Nakajima, Y.; Moriyoshi, K.; Ishii, T.; Akazawa, C.; Nakanashi, S. Molecular Characterization of NMDA and Metabotropic Glutamate Receptors. Ann. N.Y. Acad. Sci. 1993, 707, 153-164. [CrossRef]

50. Tejero-Taldo, M.I.; Chmielinska, J.J.; Gonzalez, G.; Mak, I.T.; Weglicki, W.B. N-Methyl-d-aspartate Receptor Blockade Inhibits Cardiac Inflammation in the Mg2+-Deficient Rat. J. Pharmacol. Exp. Ther. 2004, 311, 8-13. [CrossRef]

51. Tejero-Taldo, M.I.; Chmielinska, J.J.; Weglicki, W.B. Decreased VHL results in VEGF up-regulation in the magnesium deficient rat heart (abstract). J. Mol. Cell Cardiol. 2006, 40, 904. [CrossRef]

52. Chmielinska, J.J.; Tejero-Taldo, M.I.; Mak, I.T.; Weglicki, W.B. Intestinal and cardiac inflammatory response shows enhanced endotoxin receptor (CD14) expression in magnesium deficiency. Mol. Cell. Biochem. 2005, 278, 53-57. [CrossRef] [PubMed] 
53. Tejero-Taldo, M.I.; Chmielinska, J.J.; Weglicki, W.B. Magnesium deficiency stimulates angiogenesis in the rat heart (abstract). J. Mol. Cell Cardiol. 2004, 36, 631.

54. Tejero-Taldo, M.I.; Chmielinska, J.J.; Weglicki, W.B. Chronic dietary Mg2+ deficiency induces cardiac apoptosis in the rat heart. Magnes. Res. 2007, 20, 208-212. [PubMed]

55. Ho, W.-Z.; Lai, J.P.; Zhu, X.H.; Uvaydova, M.; Douglas, S.D. Human monocytes and macrophages express substance P and neurokinin-1 receptor. J. Immunol. 1997, 159, 5654-5660.

56. Lai, J.-P.; Douglas, S.D.; Ho, W.-Z. Human lymphocytes express substance P and its receptor. J. Neuroimmunol. 1998, 86, 80-86. [CrossRef]

57. Khare, V.K.; Albino, A.P.; Reed, J.A. The neuropeptide/mast cell secretagogue substance P is expressed in cutaneous melanocytic lesions. J. Cutan. Pathol. 1998, 25, 2-10. [CrossRef]

58. Cioni, C.; Renzi, D.; Calabrò, A.; Annunziata, P. Enhanced secretion of substance P by cytokine-stimulated rat brain endothelium cultures. J. Neuroimmunol. 1998, 84, 76-85. [CrossRef]

59. Scholzen, T.E.; Steinhoff, M.; Bonaccorsi, P.; Klein, R.; Amadesi, S.; Geppetti, P.; Lu, B.; Gerard, N.P.; Olerud, J.E.; Luger, T.A.; et al. Neutral endopeptidase terminates substance P-induced inflammation in allergic contact dermatitis. J. Immunol. 2001, 166, 1285-1291. [CrossRef]

60. Wang, L.; Sadoun, E.; Stephens, R.E.; Ward, P.E. Metabolism of substance P and neurokinin A by human vascular endothelium and smooth muscle. Peptides 1994, 15, 497-503. [CrossRef]

61. Nadel, J.A. Peptidase modulation of neurogenic inflammation. In Neurogenic Inflammation; Geppetti, P., Holzer, P., Eds.; CRC Press: Boca Raton, FL, USA, 1996; pp. 115-127.

62. Lesser, M.; Fung, K.; Choi, H.S.; Yoo, O.H.; Cardozo, C. Identification of two zinc metalloendopeptidases in alveolar macrophages of rats, guinea pigs, and human beings. J. Lab. Clin. Med. 1992, 120, 597-603.

63. Iwamoto, I.; Kimura, A.; Ochiai, K.; Tomioka, H.; Yoshida, S. Distribution of NEP activity in human blood leukocytes. J. Leukad. Biol. 1991, 49, 116-125. [CrossRef] [PubMed]

64. Lauderback, C.M.; Hackett, J.M.; Huang, F.F.; Keller, J.N.; Szweda, L.I.; Butterfield, D.A. The glial glutamate transporter, GLT-1, is oxidatively modified by 4-hydroxy-2-nonenal in the Alzheimer's disease brain: The role of Abeta1-42. J. Neurochem. 2001, 78, 413-416. [CrossRef] [PubMed]

65. Wang, D.-S.; Iwata, N.; Hama, E.; Saido, T.C.; Dickson, D.W. Oxidized neprilysin in aging and Alzheimer's disease brains. Biochem. Biophys. Res. Commun. 2003, 310, 236-241. [CrossRef] [PubMed]

66. Mak, I.T.; Kramer, J.H.; Chmielinska, J.J.; Khalid, M.H.; Landgraf, K.M.; Weglicki, W.B. Inhibition of neutral endopeptidase potentiates neutrophil activation during Mg-deficiency in the rat. Inflamm. Res. 2008, 57, 300-305. [CrossRef] [PubMed]

67. Mak, I.T.; Kramer, J.H.; Weglicki, W.B. Suppression of neutrophil and endothelial activation by substance P receptor blockade in the Mg-deficient rat. Magnes. Res. 2003, 16.

68. Mak, I.T.; Komarov, A.M.; Wagner, T.L.; Stafford, R.E.; Dickens, B.F.; Weglicki, W.B. Enhanced NO production during $\mathrm{Mg}$ deficiency and its role in mediating red blood cell glutathione loss. Am. J. Physiol. Physiol. 1996, 271, C385-C390. [CrossRef]

69. Tejero-Taldo, M.I.; Kramer, J.H.; Mak, I.T.; Komarov, A.M.; Weglicki, W.B. The nerve-heart connection in the pro-oxidant response to Mg-deficiency. Heart Fail. Rev. 2006, 11, 35-44. [CrossRef]

70. Kramer, J.H.; Phillips, T.M.; Weglicki, W.B. Magnesium-deficiency-enhanced Post-ischemic Myocardial Injury is Reduced by Substance P Receptor Blockade. J. Mol. Cell. Cardiol. 1997, 29, 97-110. [CrossRef]

71. Mak, I.T.; Kramer, J.H.; Chen, X.; Chmielinska, J.J.; Spurney, C.F.; Weglicki, W.B. Mg supplementation attenuates ritonavir-induced hyperlipidemia, oxidative stress, and cardiac dysfunction in rats. Am. J. Physiol. Integr. Comp. Physiol. 2013, 305, R1102-R1111. [CrossRef]

72. Deheinzelin, D.; Negri, E.; Tucci, M.; Salem, M.; Da Cruz, V.; Oliveira, R.; Nishimoto, I.; Hoelz, C. Hypomagnesemia in critically ill cancer patients: A prospective study of predictive factors. Braz. J. Med Biol. Res. 2000, 33, 1443-1448. [CrossRef]

(C) 2020 by the authors. Licensee MDPI, Basel, Switzerland. This article is an open access article distributed under the terms and conditions of the Creative Commons Attribution (CC BY) license (http://creativecommons.org/licenses/by/4.0/). 